\title{
Identification of Active Compounds Calotropis gigantea Stem Extracts as Antimalarials Agents on Animal Infected Plasmodium berghei
}

\author{
Muhammad Shofiyullah ${ }^{1}$, Ro'ihatul Muti'ah ${ }^{2}$, Elok Kamilah Hayati ${ }^{1},{ }^{3}$ Chrystiaji $^{\prime}$ \\ Indradmojo \\ ${ }^{1}$ Department of Chemistry, Faculty of Science and Technology, Maulana Malik Ibrahim State \\ Islamic University of Malang, Indonesia \\ ${ }^{2}$ Department of Pharmacy, Faculty of Science and Technology, Maulana Malik Ibrahim State \\ Islamic University of Malang, Indonesia \\ ${ }^{3}$ Department of Biology, Faculty of Science and Technology, Maulana Malik Ibrahim State \\ Islamic University of Malang, Indonesia \\ *e-mail: shofiyullah@ rocketmail.com
}

\begin{abstract}
Thistle (Calotropisgigantea) is a wild plant that contains secondary metabolites as a potential antimalarial drugs. This study aims to determine the content of active compound contained, the potential of ethanol extract of the stem thistle as an antimalarial, and knowing the best eluent used when TLC test. This study covers the extraction of stem thistle using maceration for 24 hours using ethanol 80\%.Stirring assisted with shaker for 3 hours. Ekstrak concentrated phytochemical test, antimalarial activity was evaluated by experimental animals mice infected by Plasmodium berghei. Data degree of parasitaemia in mice were analyzed using Minitab 16 with Test TwoWay ANOVA followed by Tukey test. The results showed that ethanol extract stem thistle contains the active compound class of triterpenoids, and potentially as an antimalarial with $\mathrm{ED}_{50}$ values $152.878 \mathrm{mg} / \mathrm{kg}$ bw were included in both categories. TLC test results showed that the best eluent for the separation of triterpenoids of stem thistle extract is benzene: chloroform (3: 7) which produced 12 spots with $\mathrm{Rf}$ values of $0.04 ; 0.06 ; 0.14 ; 0.21 ; 0.29 ; 0.35 ; 0.41 ; 0.48 ; 0.80 ; 0.84 ; 0.88 ; 0.91$.
\end{abstract}

Keywords: Antimalarial, Calotropisgigantea , Ethanol 80\%, Plasmodium berghei , Thin Layer Chromatography

\section{INTRODUCTION}

Malaria is an infectious disease caused by parasites (protozoan) from the genus Plasmodium that can be transmitted through the bite of female Anopheles. Plasmodium is a dangerous parasite that causes malaria have been known since ancient Greece. Plasmodium is transmitted one person to another through intermediaries mosquitoes of the Anopheles species.

The first drug used for the disease is quinine. This drug is used as the primary drug of malaria since 1600 until the 1800s. Along with the advance of science and technology, the discovery of other drugs as an antimalarial was growing rapidly [7].

Plasmodium resistance to malaria drugs have been reported, among others, the resistance of Plasmodium falciparum (P. falciparum) malaria drug class of 4-aminokuinolin (chloroquine and amodiaquine). Treatment of malaria which is based on natural resources, especially plant, has been used since long by human-like leaves of Artemisia in Papua [1]. The use of herbs as medicine is often based on rational considerations with respect to knowledge of the chemical compounds found in plants that are known to have biological activity. However, there are also among these plants were unknown chemical compounds that need further research. 
One that could potentially be used as a medicinal plant is a plant thistle (Utami, 2008). Thistle is a wild plant that is rich in chemicals. According Hariana (2006), bark, roots, leaves, flowers and thistle sap useful as a drug to treat a variety of diseases, such as scabies, cough, measles, toothache and kutil. Stem thistle is also known to contain tannins, saponins, and acid oxalate [8], and according Kailavani (2003) found that the ethanol extract stem thistle found to contain terpenoid compounds.

According to research conducted by Mudi and Bukar (2011) showed that there were anti-plasmodia activity (antimalarial) by leaf extract of Calotropisprocera, which has been known that plants of the family have almost the same chemical content. Based on this research, it needs to do a study on the identification of antimalarial compounds thistle stem (Calotropisgigantea) as a plant that has been less than helpful. Stem thistle chosen with a view to the variations of the sample used, because it is possible at the different plants, the active compound and the potential antimalarial owned by different, besides the plant thistle is relatively abundant in Indonesia, and just as weeds, if found active compound the thistle stalks, then this plant will provide benefits and not just as a plant pest.

This study aims to determine the class of active and potential antimalarial compounds contained in the plant stem thistle (Calotropisgigantea) and know the best eluent used when TLC test.

\section{MATERIALS AND METHODS}

The materials used in this study is the plant stem thistle (Calotropisgigantea), ethanol 80\%, Reagents Dragendorff, Mayer, Lieberman-Burchard, methanol 50\%, Mg metals, $\mathrm{HCl} 2 \%$, of concentrated $\mathrm{HCl}$, chloroform, acetic acid anhydride, distilled water, a solution of $\mathrm{FeCl}_{3} 1 \%$ $\mathrm{H}_{2} \mathrm{SO}_{4}$ concentrated, ethyl acetate, acetic acid, $\mathrm{H}_{2} \mathrm{SO}_{4} 0.1 \mathrm{M}$, white male mice strain $\mathrm{Balb} / \mathrm{c}$, mice feed (pellets), heart blood from donor mice infected with the parasite, EDTA, Alsever's solution, $10 \%$ glycerol, PBS solution, Giemsa buffer, GiemsaFluka, methanol, chloroquine, CMC-Na solution $1 \%$

In the extraction process, stem thistle powder that has been in preparation weighed as much as $100 \mathrm{~g}$ and soaked with ethanol $80 \%$ for 24 hours at room temperature with shaking of $120 \mathrm{rpm}$ for 3 hours using a shaker. The filtrate obtained was concentrated by rotary vacuum evaporator to obtain a concentrated extract. The concentrated extract in an oven at $37^{\circ} \mathrm{C}$ to remove residual ethanol. Then weighed to obtain a constant weight.

The next test antimalarial. Thistle extract test by invivo in experimental animals. Experimental animals used were male mice Musmusculus were infected by Plasmodium berghei and grouped into 6 groups, non-infectious, positive control group (chloroquine dose of $5.71 \mathrm{mg} / \mathrm{kg}$ bw), the negative control group, the stem thistle extract at a dose $0,1 \mathrm{mg} / \mathrm{kg}$ bw, stem thistle extract at a dose of $1 \mathrm{mg} / \mathrm{kg}$ bw, stem thistle extract at a dose of $10 \mathrm{mg} / \mathrm{kg} \mathrm{bw}$. Therapy is done every day for 4 days. Observations degree of parasitaemia done every day 0,1 st, 2 nd and 3rd. Phytochemical test is a qualitative analysis used to determine the content of classes of active compounds contained in a material. Phytochemical test in this study include, alkaloids test, flavonoids test, tannins test, saponins test, and triterpenoids test. The positive results of phytochemical test further identified using thin layer chromatography (TLC).

The identification process refers to literature sources Harborne (1987) and Sastrohamidjojo (1985). Concentrated extract stem thistle $1000 \mathrm{mg}$ dissolved in $1 \mathrm{ml}$ of ethanol $80 \%$. Then, put the mixture into a eluent container and closed eluent container for 1 hour to saturate the eluent steam.

Separation by TLC was used silica gel $\mathrm{F}_{254}$ plates. Activation silica plate in advance by heating in an oven at a temperature of $60-70{ }^{\circ} \mathrm{C}$ for 10 minutes. Each plate is cut to the size of $1 \times 10^{2} \mathrm{~cm}$. Ethanol extract stem thistle spotted on the plate using capillary tube. Then eluted with the mobile phase each class of compounds. Sprayed th spot with reagent and examined 
under UV light at a wavelength of $254 \mathrm{~nm}$. Then the stain was observed and calculated Rf values. Data analysis was performed using SPSS and Minitab 16.

\section{RESULT AND DISCUSSION}

Concentrated extract obtained was transferred to a glass vial that had previously been weighed empty. Widuri concentrated extract stem is solid green. Concentrated extract obtained is not entirely free from solvents. For get more concentraded extracts, concentrated extract oven at temperature of $37^{\circ} \mathrm{C}$ and weighed, this treatment done repeatedly, to obtain a concentrated extract a constant weight, and the concentrated extract obtained widuri rod weighing 4.55 grams. This extract is used for in vivo antimalarial test, a test group of active compounds, and identification of active compounds by TLC

Drug therapy is done when the degree parasitema extract has reached 1-5\%, calculated as day 0 . Appropriation of the test substances carried out once a day for 4 consecutive days due to malaria drugs gift enough once and within 4 days was able to inhibit the growth of the parasite effectively (Kusumawardhani, et al, 2008) Activity antimalarial determined by measuring the degree of parasitaemia on day 0 until day 4 , aims to determine the degree of parasitaemia all mice after being in the range of approximately $1-5 \%$ on the day of execution of the therapy. Examination of the degree of parasitaemia on day 1 until the day 4 aims to know the profile of the parasite developments during therapy. Degree examination results parasitaemia from day 0 to day 4 shown in Figure 1

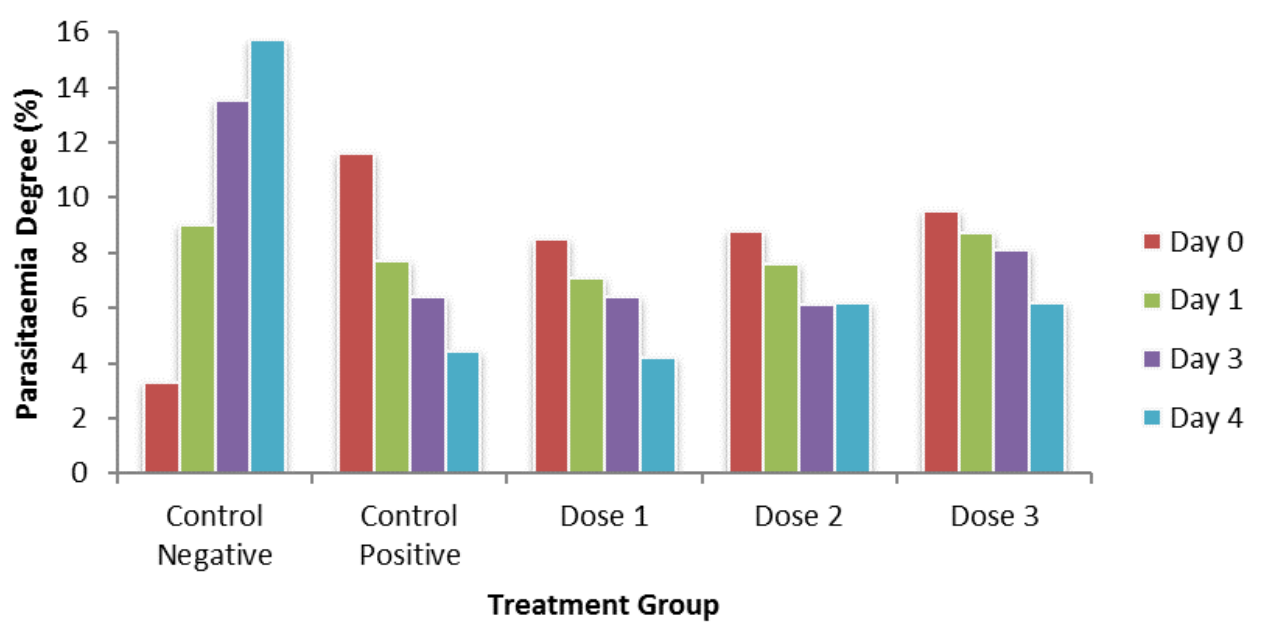

Fig 1. we can see that the degree of parasitaemia in the negative control increases with each passing day, whereas the positive control and a dose of 1,2, and 3, the value of the degree of parasitemianya decreased with increasing days. This is caused by differences in the body's reaction to different mice such as metabolism and immune system.

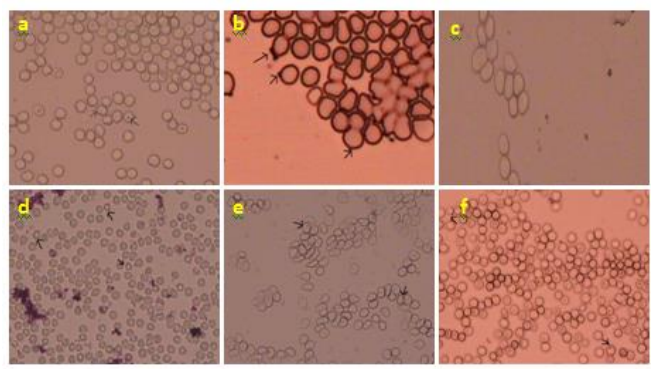

Fig 2. Infected erythrocytes Day-0 Picture a. Negative controls, b. Positive control, c. Non Infection, d. Dose of $0.1 \mathrm{mg} / \mathrm{kg}$ e. A dose of $1 \mathrm{mg} / \mathrm{kg}$, and $\mathrm{f}$. A dose of $10 \mathrm{mg} / \mathrm{kg}$ 
In Figure 2 can be seen that quite a lot of erythrocytes infected with Plasmodium berghei, except the image $\mathrm{c}$, because the image $\mathrm{c}$ is a group of non-infectious, in which groups of non-infectious is not in infection with Plasmodium berghei. Unlike Figure 4.2 in Figure 4.3 below shows that erythrocytes infected with Plasmodium berghei less, it indicates that a decline in the activity of Plasmodium berghei in mice red blood cells.

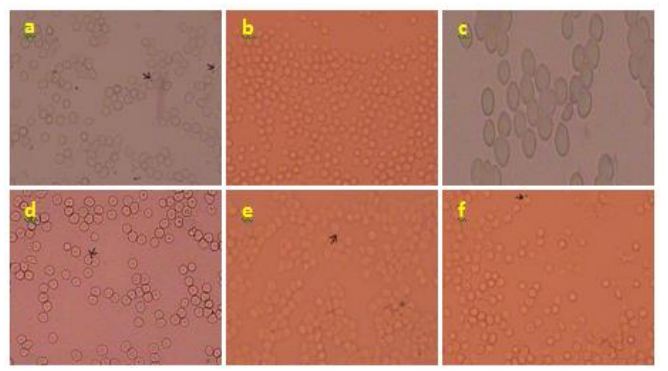

Fig 3. Infected erythrocytes Day-3 Figure a. Negative controls, b. Positive control, c. Non Infection, d. Dose of $0.1 \mathrm{mg} / \mathrm{kg}, \mathrm{b}$. A dose of $1 \mathrm{mg} / \mathrm{kg}$, and c. A dose of $10 \mathrm{mg} / \mathrm{kg}$

Parasitaemia degree on negative controls increase from day 0 of $3.3 \%$ and an increase every day that is on days 1 to $9 \%$, the 2 nd day of $13.5 \%$ and the 3 rd day of $15.7 \%$. An increase in the degree of parasitaemia drastically negative control caused by the withholding of treatment drugs only giving CMC-Na, where CMC-Na did not have any effect on the inhibition of erythrocyte, so that only the antibodies in mice who hinder the development of an infection in the erythrocytes of mice without the aid of drugs. On the positive control treatment, the dose 1 , dose 2 and dose 3 decreased the degree of parasitaemia, from these data it is known that there is a decrease in the amount of Plasmodium berghei infection in the erythrocytes, so that there is the influence of drugs that help decrease degree of parasitaemia in mice erythrocytes. On the positive controls decreased from day 0 degrees parastemia which has decreased by $11.6 \%$ to $7.7 \%$ on day 1 and a decreased continually every day is on the 2 nd day of $6.4 \%$ and 3rd day of $4.4 \%$. Positive control group is the group that carried out the infection by Plasmodium berghei in mice and made provision of chloroquine in mice. In the group of dose 1, dose 2 and dose 3, the most excellent inhibition occurred at doses of 1 , It can be seen in Table 1:

Table 1 Percent inhibition on day 3

\begin{tabular}{c|c|c}
\hline No. & Treatment & \% Inhibition \\
\hline 1. & Dose 1 & 73,5 \\
2. & Dose 2 & 60,8 \\
3. & Dose 3 & 60,5 \\
\hline
\end{tabular}

From Table 1, it can be seen that the highest $\%$ inhibition occurred at doses 1 . The degree of parasitaemia day 0 at doses of 1 is equal to $8.5 \%$ and decreased on day 1 that is equal to $7.1 \%$, the decline continues to occur on the day 2 nd amounted to $6.4 \%$ and on day 3 , namely by $4.2 \%$.

Determination of the $50 \%$ effective dose $\left(\mathrm{ED}_{50)}\right.$ in this study using probit \% inhibition of parasite growth for 4 days followed by linear regression analysis using Microsoft Office Excel, and performed well probit analysis with Minitab. The reason for choosing probit analysis for dose response relationship is naturally sigmoid (Vincent 2008 in Husna, 2011). Thus the curve obtained with a dose-response relationship between the dose-response curve is sigmoid. 
Results of analysis and calculation of the $\mathrm{ED}_{50}$ in Appendix 6.

Linear equation obtained by inserting the value of inhibition that has been transformed in probit form in Microsoft Excel to get the linear equation with $\mathrm{R}^{2}$ value of 0.83 , wherein $\mathrm{R}^{2}$ is the coefficient of determination against Probit log dose inhibition of parasite pertumbuha.

Determination of ED 50 is done using statistic data with Probit analysis method, and the $\mathrm{ED}_{50}$ calculation results obtained from the calculation using the SPSS Probit analysis is $152,878 \mathrm{mg} / \mathrm{kg}$ bw.

According to Munoz, et al. (2000) antiplasmodium activity in vivo (inhibition of $P$. berghei) seen from the $\mathrm{ED}_{50}$ values. $\mathrm{ED}_{50}$ values are grouped into very good when $\mathrm{ED}_{50} \leq 100 \mathrm{mg} / \mathrm{kg} / \mathrm{day}$, both when $\mathrm{ED}_{50}=101-250 \mathrm{mg} / \mathrm{kg} /$ day, fair when $\mathrm{ED}_{50} 251-500 \mathrm{mg} / \mathrm{kg} / \mathrm{day}$, and inactive if $>500$ $\mathrm{mg} / \mathrm{kg} /$ day.

The separation of classes of active compounds triterpenoids by thin layer chromatography ethanol extract stem thistle showed that the eluent benzene : chloroform (3:7) capable of producing the best separation compared with others eluent, it is seen from the amount of spot produced more than othrs eluent, which is 12 spots with positive total triterpenoids as much as 5 spots. Eluent said to be good if it is capable of separating compounds in large quantities and characterized by the appearance of spot are not tailing and distance between one another spots clear [2],

This is shown as in the table below:

Table 2. TLC test result for benzene : chloroform $(3: 7)$ on Calotropisgigantea stem extracts of ethanol $80 \%$

\begin{tabular}{c|c|c|c}
\hline Each Spot Rf & $\begin{array}{c}\text { Before Sprayed } \\
\text { Reagent }\end{array}$ & $\begin{array}{c}\text { After Sprayed } \\
\text { Reagent }\end{array}$ & $\begin{array}{c}\text { Compounds } \\
\text { Suspect }\end{array}$ \\
\hline 0,14 & Pink & Purple & Triterpenoid \\
0,21 & Pink & Purple & Triterpenoid \\
0,29 & Pink & Purple & Triterpenoid \\
0,41 & Pink & Purple & Triterpenoid \\
0,84 & Red & Red & Triterpenoid \\
\hline
\end{tabular}

From table 2 it can be seen of benzene eluent :chloroform (3: 7) yielded considerable spot which is 12 spots, and the spot of the 12, only 5 spot assumed as stain triterpenoids. According to Rita (2010) class of compounds triterpenoids results of TLC after being sprayed with Lieberman- Burchard reagent is indicated by the formation of red stain purple and purple. From the table above it can be seen that in benzene eluent: chloroform (3: 7) spots 3, 4, 5, 7, purple with $\mathrm{Rf}$ value of 0,$14 ; 0.214 ; 0.29 ; 0.41$ and 10 show the formation of stain red with $\mathrm{Rf}$ value of 0.84 . Based color stain obtained, assumed the ethanol extract contained triterpenoid compounds. Benzene eluent : chloroform (3:7) is a semi-polar eluent, so it can be assumed that the triterpenoids compounds contained in the ethanol extract of the thistle stems are semi-polar as well.

\section{CONCLUSION}

The identification results $80 \%$ ethanol extract of the stem thistle (Calotropisgigantea) showed a class of compounds triterpenoids. In the test the effectiveness of antimalarial $80 \%$ ethanol extract of the stem thistle (Calotropisgigantea) showed $\mathrm{ED}_{50}$ amounted to $152.878 \mathrm{mg} / \mathrm{kg}$. Based on the value range antimalarial efficacy, potency is categorized as good. TLC test results on stem thistle extract is known that the use of benzene eluent: chloroform with a ratio of 3:7 is the best eluent for the separation of triterpenoids of stem thistle extract that produces 5 spot triterpenoids. 


\section{REFERENCES}

[1] Aryanti, Eamaynti, T.M., Prinadi, K.I., dan Dewi, R.M.. 2006.. 17 (2), 81-84T Alizadeh; MR Ganjali; M Zare; P Norouzi, Food Chemistry, 2012, 130, 1108-1114.

[2] Harborne, J. B. 1987.Metode Fitokimia Penuntun Cara Modern Menganalisis Tumbuhan. Diterjemahkan oleh Kosasih Padmawinata dan Iwang Soediro.Bandung: Penerbit ITB.

[3] Hariana, A. 2006, Journal of Chromatography, 2004, B (807), 343-356.

[4] Husna, A.N., 2011. Jurusan Kimia Fakultas Sains danTeknologi UIN Malang.

[5] Indrayani. L., Soetjipto, H., Sihasale, L. 2006.Skrinning Fitokimia dan Uji Toksisitas Ekstrak Daun Pecut Kuda (Stachytarphetajamaicensis L. vahl) terhadap Larva Udang Artemia Salina leach. Salatiga: Fakultas Sains dan Matematika Universitas Kristen SatyaWacana.

[6] Kalaivani, R., Thangmani, P., dan Balakrishnan V., Malaya Journal of Biosciences, 2013. ISSN 2348-6236.

[7] Milhous, W.K. and Kyle, D.F. 1998. Introduction The Modes of Action of and Mechanism of Resistence to Antimalarias.In Irwin W. Sherman. Malaria:Parasite Biology, Pathogenesis and protection. Washington D.C.:ASM Press.

[8] Redaksi Agromedia. 2008. Buku Pintar Tanaman Obat, 431 Jenis Tanaman Penggempur Aneka Penyakit. Jakarta: PT. Agromedia Pustaka.

[9] Rita, W. S., 2010. Isolasi, Identifikasi, dan Uji Aktivitas Antibakteri Senyawa Golongan Triterpenoid pada Rimpang Temu Putih (Curcuma zedoaria (Berg.) Roscoe). Bukit Jimbaran: FMIPA Universitas Udayana.

[10] Utami, P. 2008. Buku Pintar Tanaman Obat .Jakarta:Agromedia Pustaka 